\title{
The Cytotoxic Effects of Humic Acid on Human Breast Cancer Cells ${ }^{\dagger}$
}

\author{
Asli Aykac 1,*, Eda Becer 2,3, Tuğçe Balcı Okcanoğlu ${ }^{4}$, Meryem Güvenir ${ }^{4}$, Kaya Süer ${ }^{5}$ and \\ Seda Vatansever ${ }^{3,6}$ \\ 1 Department of Biophysics, Faculty of Medicine, Near East University, Nicosia 99010, Cyprus \\ 2 Department of Biochemistry, Faculty of Pharmacy, Near East University, Nicosia 99010, Cyprus; \\ eda.becer@neu.edu.tr \\ 3 Experimental Health Sciences Research Center, Near East University, Nicosia 99010, Cyprus; \\ seda.vatansever@neu.edu.tr \\ 4 Vocational School of Health Sciences, Near East University, Nicosia 99010, Cyprus; \\ tbalcii@gmail.com (T.B.O.); meryemguvenir@hotmail.com (M.G.) \\ 5 Department of Infectious Diseases and Clinical Microbiology, Faculty of Medicine, Near East University, \\ Nicosia 99010, Cyprus; kayasuer56@gmail.com \\ 6 Department of Histology and Embryology, Faculty of Medicine, Celal Bayar University, Manisa, Turkey \\ * Correspondence: asli.aykac@neu.edu.tr \\ + Presented at the 2nd International Cell Death Research Congress, Izmir, Turkey, 1-4 November 2018.
}

Published: 7 December 2018

\begin{abstract}
Breast cancer is the most common cancer among women and in order to create alternative treatments different types of in vivo and in vitro studies have used various plant-based therapeutic agents. Humic acid (HA) induces apoptosis and has various pharmacological properties including anti-inflammatory and anti-proliferative effects. In our study, we examined the cytotoxic effects of $\mathrm{HA}$ at concentrations of 5, 10,20,50 and $100 \mu \mathrm{g} / \mathrm{mL}$ in human breast adenocarcinoma MCF-7 cell line for 24 and $48 \mathrm{~h}$. By using MTT method, it has been found out that HA $100 \mu \mathrm{g} / \mathrm{mL}$ had cytotoxic effect on human breast adenocarcinoma MCF-7 cell line at both 24 and $48 \mathrm{~h}$; also found out that the effective dose of HA at the same time ( 24 and $48 \mathrm{~h}$ ) was $50 \mu \mathrm{g} / \mathrm{mL}$. The results of our study will shed light on the development of alternative therapeutic approaches in the treatment of cancer by evaluating the cytotoxic effect of HA.
\end{abstract}

Keywords: humic acid; human breast adenocarcinoma MCF-7 cell line; MTT

\section{Introduction}

In recent years, the use of natural products and medicinal plants has become increasingly widespread in order to protect the general health of individuals, to prevent and treat diseases. Nowadays, interest in antioxidant compounds that can delay or prevent oxidative damage by inactivating free radicals is increasing worldwide. Humic acid (HA), is the most active ingredient of the main content of organic substances in the soil called humus. Reactive groups such as carboxyl, phenol, quinone in HA molecules give mineral and antioxidant properties to acids [1]. Humus and the products obtained from humus are used in agricultural and biomedical fields. It is possible to count anti-viral, anti-inflammatory, anti-oxidant, anti-tumor, anti-toxin among the most known activities of HA substances [2-6]. Many researchers have suggested that HA has the power to protect against cancers and cancer-causing viruses. This suggests that HA has different biological activities such as cancer prophylaxis and treatment, as well as decreased cell proliferation and decreased angiogenesis [7]. Due to a report by the WHO that breast cancer is at the forefront of women's prevalence and cancer-related deaths, research on the treatment of breast cancer is still ongoing. 
The cytotoxic effect of HA in human breast adenocarcinoma MCF-7 cell line was aimed in this study by measuring cell viability with MTT assay.

\section{Materials and Methods}

\subsection{Purification of Humic Acid}

HA (Sigma-Aldrich Co. Darmstadt, Germany) was dissolved in $100 \mathrm{~mL} \mathrm{NaOH}$ solution ( $\mathrm{pH}>$ 10), and then insoluble fraction was separated by filtration. The solution was acidified with $100 \mathrm{~mL}$ $\mathrm{HCl}$ to a $\mathrm{Ph}<2.0$ to sediment the HA, and to soluble fractions which will bind to HA. Any precipitate that formed was collected by centrifugation at $3000 \times \mathrm{g}$ for $30 \mathrm{~min}$, and re-dissolved in $100 \mathrm{~mL} \mathrm{NaOH}$. In order to obtain the purest HA, the alkaline acid treatment was repeated three times as described by Schnitzers [8]. After that, the purified HA was freeze-dried to a powder form and it was stored as a dried powder which then dissolved in PBS $(\mathrm{pH}=7.4)$ before the experiments [9]. Finally, stock solutions were prepared at 5, 10, 20, 50 and $100 \mu \mathrm{g} / \mathrm{mL}$ filters.

\subsection{Cell Line and Cell Culture}

Human breast adenocarcinoma MCF-7 cell line (ATCC: HTB-22) was maintained in culture in RPMI-1640 medium (Biochrom, FG1215, Berlin, Germany) including 10\% fetal bovine serum (Capricorn Scientific, FBS-11B, Ebsdorfergrund, Germany), 1\% L-glutamine (EMD Millipore, K0282, Darmstadt, Germany) and 100 unit $/ \mathrm{mL}$ of \% penicillin, and $100 \mathrm{unit} / \mathrm{mL}$ of streptomycin (Biochrom, A2213). Cells were cultured in a humidified atmosphere at $37{ }^{\circ} \mathrm{C}$ in $5 \% \mathrm{CO}_{2}$ and the medium was changed every 2 days. When the cells were $80 \%$ confluent, they were routinely sub-cultured using $0.25 \%$ trypsin-EDTA solution (Biochrom, L2143). After a sufficient number of cells have been produced, some of the cells were stored $-80^{\circ} \mathrm{C}$ by cell freezing medium. The proliferation, passages and tracking of the cells were regularly monitored by using an inverted microscope. When the cells were confluent, they were removed from the flasks by using trypsin-EDTA solution and transferred to 96 well dishes. HA diluted in culture medium at five different concentrations $(5,10,20,50$ and 100 $\mu \mathrm{g} / \mathrm{mL}$ ) for MTT assay. Cell suspensions were first prepared at densities of 3000 cell per each well of 96-well culture dishes and plated in triplicate for each acid concentration. Medium (100 $\mu \mathrm{L})$ without HA was used as a positive control, and only medium which did not contain any cells and HA was used as a negative control. MCF-7 cells were treated with the concentrations as previously mentioned for 24 and $48 \mathrm{~h}$. The cells were incubated at $37^{\circ} \mathrm{C}$ for $4 \mathrm{~h}$. After that, $100 \mu \mathrm{L}$ DMSO was added each well and the absorbance was immediately determined at $540 \mathrm{~nm}$ in an UV-visible spectrophotometer multi plate reader (Versa Max, Molecular Device, Sunnyvale, CA, USA).

\section{Results and Discussion}

It is shown cells in standard culture medium by Figure 1.

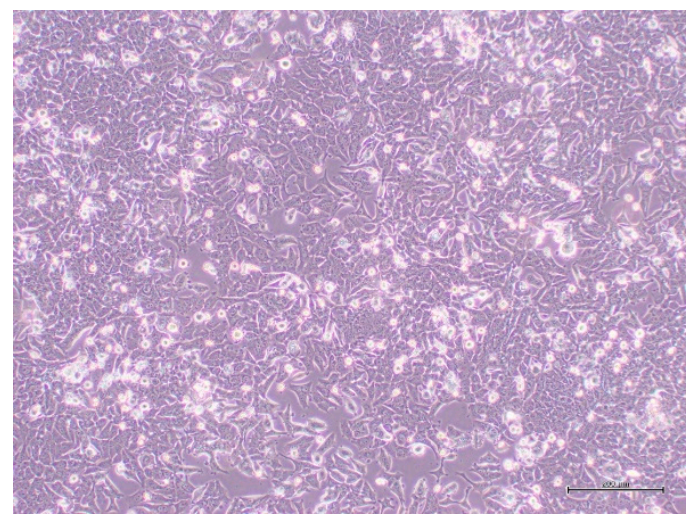

Figure 1. MCF-7 cells imaged under an inverted microscope, scale bars $=200 \mu \mathrm{m}$. 
Human breast adenocarcinoma MCF-7 cells were treated with HA at concentrations of 5, 10, 20, 50 and $100 \mu \mathrm{g} / \mathrm{mL}$ for 24 and $48 \mathrm{~h}$. Cell viability was determined by MTT assay as described previously. Our results show that HA prepared at $100 \mu \mathrm{g} / \mathrm{mL}$ dose had a cytotoxic effect at 24 and 48 $\mathrm{h}(p<0.005)$ while the $50 \mu \mathrm{g} / \mathrm{mL}$ HA was determined to be the most effective dose on MCF-7 cell lines at 24 and $48 \mathrm{~h}$ (Figure 2).

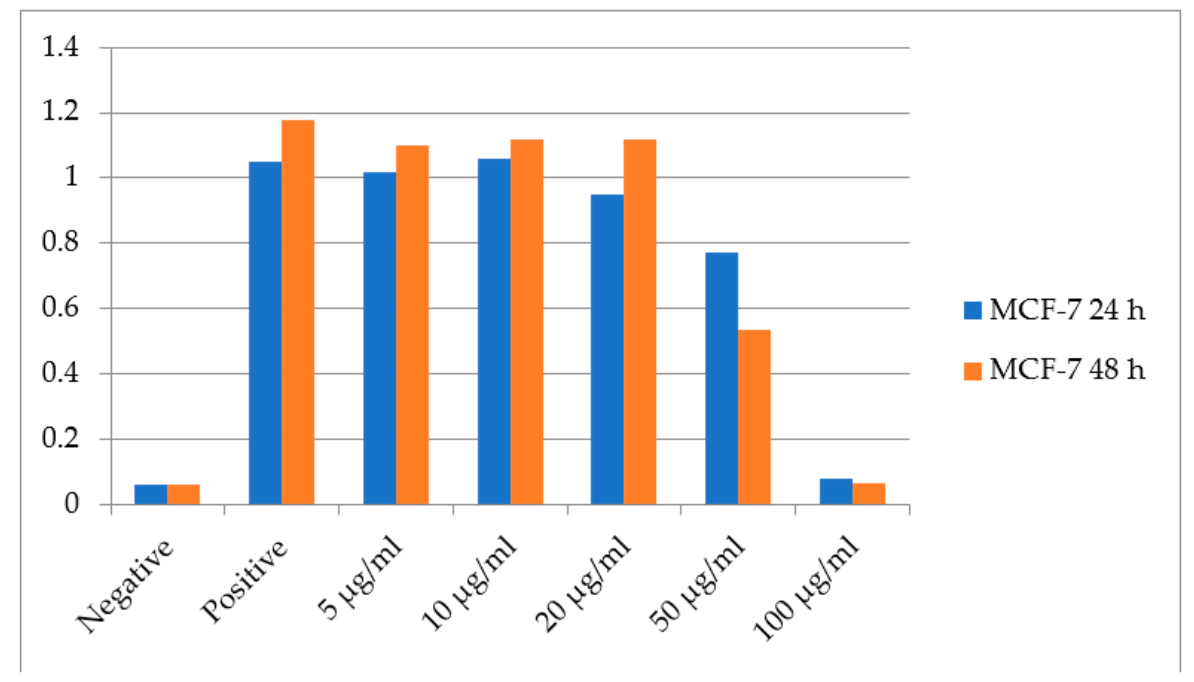

Figure 2. The results of MTT assay showing the effects of humic acid on human breast cancer cells MCF-7 at different concentrations for 24 and $48 \mathrm{~h}$.

HA have been suggested to be an etiological factor of cancer as HA causes oxidative damage which is known to be a potential reason of carcinogenesis [10]. HA have been suggested to be an etiological factor of cancer, with HA induced oxidative damage as a potential causative mechanism of carcinogenesis [10]. HA maintains its uncertainty over human breast adenocarcinoma cells, and to date there are no published reports directly examining the effect of HA on breast cancer in vitro or in vivo studies. The cytotoxic effect of HA on human breast adenocarcinoma cells was first investigated in this study. In one study, they reported that HA used at different concentrations in the range of $100-1000 \mu \mathrm{g} / \mathrm{mL}$ in HeLa and SiHa cells and found out that there is no cytotoxic effect at $48 \mathrm{~h}$ less than $500 \mu \mathrm{g} / \mathrm{mL}$ concentrations. In the same study, the authors reported that $500 \mu \mathrm{g} / \mathrm{mL}$ and 300 $\mu \mathrm{g} / \mathrm{mL}$ of HA increased the anti-proliferative effect in human cervical cancer cells [10]. Our results supported that HA which is prepared at $100 \mu \mathrm{g} / \mathrm{mL}$ dilution have cytotoxic effect at both 24 and $48 \mathrm{~h}$ incubation in MCF-7 cells. In addition, at 24 and $48 \mathrm{~h}$ incubation with $50 \mu \mathrm{g} / \mathrm{mL} \mathrm{HA}$, we were found to be the effective dose on MCF-7 cells.

\section{Conclusions}

Cancer is a leading cause of death worldwide. The possibility that intake of natural substances might reduce risk of cancer has attracted attention as eventual chemo-preventive or chemotherapeutic agent. Especially, effective dose of the component which are using to treatment of cancer cells, it is really important. Because, during cancer treatment policy, rather than cytotoxic dose, effective dose should be determined before using patient treatment.

Acknowledgments: We work was supported by Experimental Health Sciences Research Center, Near East University, Cyprus [Grant number SAG-2016-2-018]. 


\section{References}

1. Ay, F. Hümik asit ve hümik asit kaynaklarının jeolojik ve ekonomik önemi. Cumhuriyet Üniversitesi Fen Fak. Fen Bilim. Derg. 2015, 36, 28-51.

2. Klöcking, R.; Helbig, B. Medical and Applications of Humic Substances, 1st ed.; Steinbüchel, A., Marchessault, R.H., Eds.; WILEY-VCH: Weinheim, Germany, 2005; pp. 3-16.

3. Efimova, I.; Khil'ko, S.; Smirnova, O. Antioxidant activity of humic acids in radical-chain oxidation processes. Russ. J. Appl. Chem. 2012, 85, 1351-1354.

4. Kodama, H.; Denso. Antitumor effect of humus extract on murine transplantable L1210 leukemia. J. Vet. Med. Sci. 2007, 69, 1069-1071.

5. Jooné, G.K.; van Rensburg, C.E.J. An in vitro investigation of the anti-inflammatory properties of potassium humate. Inflammation 2004, 28, 169-174.

6. Krzemiński, T.F.; Nożyński, J.K.; Grzyb, J.; Porc, M. Angiogenesis and cardioprotection after TNF- $\alpha$ Tolpa Peat Preparation treatment in rat's hearts after experimental myocardial infarction in vivo. Vascul. Pharmacol. 2005, 43, 164-170.

7. Dizman, M.; Tutar, A.; Kahraman, M.R.; Turan, M.; Horuz, A. Hümik maddelerin ilaç olarak kullanılması ve insan sağlığına etkileri. SAÜ Fen Edebiyat Derg. 2012, 1.

8. Schnitzers, M.T. Organic matter characterization. In Methods of Soil Analysis. Part 2. Chemical and Microbiological Properties, Page, A.L., Ed.; Academic Press: New York, NY, USA, 1982; pp. 581-594.

9. Ting, H.C.; Cheng-Chieh Yenb, C.C.; Chend, W.K.; Wen-Huei Change, W.H.; Choua, M.C.; Fung-Jou Lua, F.J. Humic acid enhances the cytotoxic effects of arsenic trioxide on human cervical cancer cells. Environ. Toxicol. Pharmacol. 2010, 29, 117-125.

10. Hseu, Y.C.; Chen, S.C.; Chen, Y.L.; Chen, J.Y.; Lee, M.L.; Lu, F.J.; Wu, F.Y.; Lai, J.S.; Yang, H.L. Humic acid induced genotoxicity in human peripheral blood lymphocytes using comet and sister chromatid exchange assay. J. Hazard. Mater. 2008, 153, 784-791.

(C) 2018 by the authors. Licensee MDPI, Basel, Switzerland. This article is an open access article distributed under the terms and conditions of the Creative Commons Attribution (CC BY) license (http://creativecommons.org/licenses/by/4.0/). 